Kultura słowa w komunikacji kaznodziejskiej

- uwagi na marginesie tekstów homiletycznych i oficjalnych wypowiedzi kościelnych lat dziewięćdziesiątych

Dorota Zdunkiewicz-Jedynak 


\title{
DOROTA ZDUNKIEWICZ-JEDYNAK
}

\author{
Kultura słowa w komunikacji kaznodziejskiej - \\ - uwagi na marginesie tekstów homiletycznych i oficjalnych \\ wypowiedzi kościelnych lat dziewięćdziesiątych
}

$\mathrm{R}$ ozważania o języku w Kościele katolickim podejmuję w czasie, gdy znalazł się On po 1989 roku w odmiennych warunkach społecznych i politycznych. Uległa zmianie jego pozycja: z Kościoła ludowego, wtopionego w Naród, pełniącego funkcję integracyjną stał się zaledwie fragmentem społeczności pluralistycznej".

W tej nowej sytuacji obserwuje się niespodzianie spadek jego autorytetu oraz krytyczną reakcję na język kościelnego przepowiadania. Wobec niej dla językoznawcy zadaniem ogromnej wagi wydaje się analiza tekstów kaznodziejskich ostatnich lat połączona ze wskazaniem takich ich właściwości językowych, które utrudniają ich komunikacyjną skuteczność. Nie chodzi przy tym o zarejestrowanie wykroczeń przeciw tradycyjnie pojmowanej kulturze języka, lecz o omówienie naruszeń normy w zakresie szeroko rozumianej kultury słowa. Być może pozwoliłoby to kaznodziejom na świadome przeciwdziałanie błędom z pożytkiem dla posługi słowa.

Przedstawione poniżej uwagi sformułowane zostały na podstawie:

1) listów i komunikatów Episkopatu z lat 1993-1995 (20 tekstów);

2) oficjalnych wypowiedzi przedstawicieli kleru dla prasy z ostatniego roku;

3) kazań i homilii radiowych z lat 1989-1990 (30 tekstów).

Te ostatnie są dość reprezentatywne dla języka, którym mówi dziś do wiernych Kościół. Ponadto z uwagi na szeroki zasięg oddziaływania stanowią one dla kaznodziejów w Polsce wzorce przepowiadania kościelnego.

Współczesna teoria komunikacji kładzie znaczny nacisk na dialogowy charakter porozumiewania się. Do najważniejszych językowych środków ułatwiających tak rozumianą komunikację należy umiejętne stosowanie form osobowych czasowników oraz zaimków osobowych. One bowiem kształtują ogólne relacje nadawczo-odbiorcze. 1. osoba liczby pojedynczej oraz zaimek ja w najwyższym stopniu sprzyjają nawiązaniu osobistego kontaktu mówiącego ze słuchaczami. $Z$ kolei 1. osoba liczby mnogiej i zaimek my kształtują u słuchaczy poczucie bliskości, eliminują przedziały między nadawcą i odbiorcą wypowiedzi.

1) W. Piwowarski, Zmiana miejsca i roli w społeczeństwie, w: Kościół w Polsce w warunkach wolności, red. K. Górski, Warszawa 1993, s. 8-11. 
Utożsamianie się kaznodziei z wiernymi znajdujące swój językowy ekwiwalent w postaci 1. osoby liczby mnogiej stanowiło jedną z fundamentalnych cech praktyki homiletycznej pierwszej połowy lat osiemdziesiątych. 2. osoba liczby mnogiej zarezerwowana była wówczas najczęściej do zwrotów, których adresatami byli nie zgromadzeni na nabożeństwie wierni, ale decydenci. Analizując kazania po 1989 roku z łatwością można dostrzec wzrastającą liczbę takich kazań, w których kaznodzieja konsekwentnie zwraca się do wiernych, używając 2. osoby liczby mnogiej. Oto przykład szczególnie jaskrawy:

1. Budujecie sobie grobowce, bo nie wierzycie w zmartwychwstanie (...) Za dużo mówicie, a nie modlicie się. Założyliście "Solidarność", a jesteście egoistami. Nazywacie się chrześcijanami, a nie jesteście Chrystusowi².

Użycie 2. osoby liczby mnogiej w cytowanym kazaniu tworzy trudną do przełamania barierę komunikacji. Ulega ona jeszcze znaczniejszemu wzmocnieniu, jeśli towarzyszy jej wyraźne przeciwstawienie kaznodziei słuchaczom, np:

2. Nawracajcie się, zmieńcie swój sposób myślenia, swój sposób życia (...) Co do mnie, bracia moi (...) modlę się nieustannie za was, abyście byli mocni $w$ wierze. (170)

Ułatwiające perswazję poczucie bliskości i współbraterstwa zastąpione zostaje trudnym do zaakceptowania przez słuchacza paternalizmem.

Wydaje się, że w zasadniczej sprzeczności z nakazem współbraterstwa stoją wszelkie sformułowania zawierające wyrazy o charakterze uogólniającym, zwłaszcza kwantyfikatory typu: nikt, nic, wszędzie itp., a także formy zakładające oczywistość sądów - oczywiście, po prostu, oczywisty:

3. Religia była w szkole od zawsze, nie musi więc wchodzić do szkół, ona po prostu tam wraca. (282)

4. Polski robotnik opowiedział się za największą wartością (...) Wszystko po to, aby ocalić skarb - Polskę, zawsze wierną Bogu. (299)

5. Domagamy się prawnego zakazu sztucznych poronień, bo prawo nie powinno pozwalać na coś tak oczywiście złego jak zabijanie niewinnych istot ludzkich. (81)

Nietrudno tymczasem zauważyć, że wokół kwestii poczęcia dziecka, aborcji roztacza się ogromny obszar pytań i wątpliwości moralnych. Nie powinny one być lekceważone, przemilczane, gdyby chciało się umożliwić wiernym wolny wybór.

Pierwszą zasadą postawy otwartości partnerów komunikacji jest szacunek także wobec adwersarzy. Najważniejsze bowiem pozostaje spotkanie w słowie z dru gim człowiekiem. Przyjrzyjmy się w tym kontekście następującym cytatom:

2 Cyt. wg Świętokrzyskie Kazania Radiowe, t. 5, opr. J. Jachimczak, Kraków 1991 (w nawiasie numer strony). 
6. Również z naszego pokolenia i europejskiego podwórka pochodzi niczym nie uzasadniony pęd do szukania odpowiedzi na pytanie o sens życia w pozachrześcijaniskich religiach wschodnich. (292)

7. Ja tego języka nie rozumiem, gdzie my jesteśmy? Przecież to chodzi o życie dziecka. Będziesz mogła spokojnie umrzeć? Zostawcie im tę ustawę, nich umrą w grzechach swoich, ale naród musi żyć (...) Bez tchnienia Ducha - będziecie jako wyschnięte kości i szkieletów ludy. (84)

W sytuacji, gdy doświadczenia społeczne wielu powojennych dziesięcioleci zrodziły lęk przed nietolerancją, pozytywną wymowę zyskują wszelkie sygnały zrozumienia ze strony kaznodziei dla złożoności sytuacji egzystencjalnej kobiet decydujących się na aborcję, złożoności wewnętrznych konfliktów, starcia różnych racji. Zestawienie jednostronnie formułowanej wypowiedzi ze skomplikowaną rzeczywistością powoduje bowiem wrażenie fałszu, utrudnia budowanie świadomości etycznej. Wyrażenie zrozumienia decyzji nie akceptowanych nie jest przecież tożsame $z$ ich usprawiedliwieniem. Stanowi ono natomiast nieoceniony skarb dla skuteczności perswazji. Jest sygnałem szacunku mówiącego dla słuchaczy, uznania ich podmiotowości i prawa wyboru poglądów i decyzji, zwłaszcza gdy są one trudne do podjęcia. Jeden z teoretyków polskiego kaznodziejstwa ks. Pagiewski napisat:

Podstawowy ruch diaiogowy polega na zwróceniu się do drugiego, na świadomym i szczerym uznaniu go za partnera dialogu. Wtedy dopiero stuchacz zaczyna dla mnie realnie istnieć, gdy moją uwagę zwracam do niego i uznaję takim, jakim jest (...). Jeśli drugiego nie uznaję w jego odmienności, w klimacie wolności i miłości (...) w zarodku zabijam komunikację. ${ }^{3}$

Rzeczywistość wyłaniająca się ze współczesnych kazań ma wyraźnie charakter dwubiegunowy. To świat, w którym panuje zarysowany znacznie ostrzej niż w latach osiemdziesiątych podział na swoich i obcych. W czasach, gdy w Polsce panował ustrój paratotalitarny, strach wobec rządów ucisku zaowocował ważną dla języka antytotalitarnego kategorią „oni” stojącą w opozycji do „my”. Ta kategoria pomagała wzmocnić poczucie jedności. W kazaniach początków lat osiemdziesiątych była ona jednak znacznie rzadziej wykorzystywana niż u progu lat dziewięćdziesiątych, choć granica między „my” i „oni” była dla wszystkich dość ostra. Dzisiaj, gdy ta dwubiegunowa orientacja świata nie jest na ogół dla ludzi tak klarowna, zdumiewa mnogość wypowiedzi kościelnych, w których silne jest przeciwstawienie „my” - „oni”. W podobnych tekstach perswazja zaczyna się od ataku na przeciwnika, który tym razem jest wewnątrz Kościoła.

8. Głupi masz ten naród, Królowo. Stare chłopy natworzyli sobie partii, jakby im tamtej było za mało (...). Odgrzewają stare przywary: pieniactwo, zawiść, warcholstwo, prywaty. Same kupce a rataje, nie potrafią być woini. Zapomnieli, czyimi są

' H. Pagiewski, Podstawowe zasady komunikacji we współczesnym kaznodziejstwie, „Homo Dei" 1975., s. 117-119. 
dziećmi, zapomnieli imię Matki, zapomnieli mowę, której ich uczyłaś, zgubili wiarę, którą im dałaś. (259)

Lektura tekstów kościelnych początku lat dziewięćdziesiątych daje wrażenie utrwalonego kompleksu stanu wojennego. Poczucie ogarniającego zewsząd zagrożenia stwarza obowiązek szukania przeciwnika, stwarza atmosferę podejrzliwości:

9. Odnosi się wrażenie, że wojna trwa nadal. Zmienił się tylko front walki, która toczy się w naszych sercach, w naszych sumieniach.(325)

10. Za mało odwagi do demaskowania zła (...) widzimy wielką potrzebę przemawiania w clomu ojczystym (...). Na każdym kroku w'ypada nam znosić ludzi niemądrych, ordynarnych, nieszczerych: tych co żyją pośród nas i nam żyć nie dają. (120)

11. W obliczu ataku sił laickich na wartości chrześcijańskie, a nierzadko narodowe, katolicy powinni zespolić wszystkie siły dla ich ocalenia, demokracja bowiem bez wartości podstawowych (...) przeradza się w jawny lub zakamuflowany totalitaryzm. (List Episkopatu Polski w sprawie wyborów do parlamentu 19 VI 93)

12. Zatruwa nas zakamuflowany ateizm, laicyzm i zorganizowany materializm praktyczny (...) narażeni (jesteśmy - D.Z.J.) na inwazję programowego liberalizmu moralnego. (List Biskupów Polskich na dzień zawierzenia Polski Najświętszej Maryi Pannie, 19 VI 93)

Jedną z dominujących cech współczesnych kazań jest właśnie kształtowanie w nich więzi z odbiorcami przez wykorzystanie kategorii przeciwnika:

13. Dlaczego są Polacy, którzy nie chcą powrotu religii do szkoły? Socjaldemokraci wnieśli sprawę do Trybunału Konstytucyjnego. Kto to są owi Polacy? Spadkobiercy tych, którzy wyrzucili religię ze szkoły, trując nas tzw. światopoglądem naukowym, mętną spuścizną klasyków marksizmu. Dlaczego oni za to nie są osądzeni? Diabet jest już osądzony, a ci, którzy są jego aniołami, nie mogą czynić nic dobrego, a złe diabli wezmą, bo to diabelska rzecz. (305)

14. W tej perspektywie można dostrzec powody, które prowadzą do nowego nieformalnego sojuszu sił postkomunistycznych z różnymi ugrupowaniami laickimi. Widzimy w tym sojusz przeciwko podstawowym wartościom moralnym i zagrożenie dla życia narodu (...) Działanie tych samych sił przejawia się również w ataku na (...) obecność religii w szkole, a także tendencyjnym odwlekaniu ratyfikacji konkordatu między Rzecząpospolitą Polską a Stolicą Apostolską (...) Trudno nie widzieć $w$ tym smutnego dziedzictwa mentalności komunistycznej i państwa totalitarnego. (Komunikat z 270 Konferencji Plenarnej Episkopatu Polski, 18 VI 1994)

15. Trwa wielki i widoczny wszędzie program deprawacji. Atakowane jest całe społeczeństwo. Mechanizm zjawiska jest prosty, choć jego autorzy doskonale ukryci. (List Biskupów Polskich na uroczystość Świętej Rodziny, 11 XII 93) 
Powyższe fragmenty ilustrują dość niebezpieczne dla współczesnego języka kościelnego zjawisko, które utrudnia komunikację. Chodzi o dość łatwe zaszeregowania, zwłaszcza wiązanie przeciwników różnego autoramentu w jedną kategorię ujętą wspólną etykietą spadkobierców komunizmu lub jak w wypowiedzi niżej cytowanej figurą przebiegłego Żyda:

16. Polacy! Obudźcie się. Nie możemy więcej tolerować rządów ludzi, którzy nie powiedzieli tego, czy pochodzą z Moskwy czy z Izraela. Gwiaz'da Dawida jest wpisana w symbol swastyki i sierpa i młota. ( ks. H. Jankowski, cyt. za "Gazetą Wyborcza", 21 VI 1995)

Wyłaniająca się z cytowanych tekstów wizja przeciwnika Kościoła niebezpiecznie przypomina figurę wroga znaną z zupełnie innych tekstów - to przede wszystkim przeciwnik zdemoralizowany, działający w sposób ukryty.

Często spotykanym zabiegiem, stosowanym, gdy mowa o ludziach, których postawy nie są akceptowane, jest niedopowiadanie, nienazywanie ich wprost. Ludzie reprezentujący postawy nie aprobowane często nazywani są zaimkiem nieokreślonym niektórzy lub też innymi wyrazami sugerującymi, że chodzi o adwersarzy nielicznych. Stwarza się przy tym sugestię, że zarówno mówiący, jak i słuchacze doskonale wiedzą, o kogo chodzi:

17. Niektórzy mówią, że istnieją wskazania lekarskie na zabicie płodu. (80)

18. Kościół taką E:wangelię będzie głosit. Nie może uczyć religioznawstwa, choć tego chcieliby niektórzy. (326)

Podobne wrażenie nieokreśloności dają powszechnie używane w badanych kazaniach nieosobowe formy czasowników:

19. Wiele mówi się obecnie o projekcie nowej ustawy, która - po raz pierwszy w polskim prawie - tak dobitnie podkreśla wartość ludzkiego życia od samego początku, od chwili poczęcia. (92)

20. W miejsce odrzuconych autorytetów i wartości wprowadza się kolorową, silnie podretuszowaną wizję życia specjalnie dobieranych idoli. Proponuje się iluzoryczny świat pełnego wyzwolenia, tolerancji (...) Młodych ludzi namawia się do korzystania z całkowitej wolności w realizowaniu wszelkich form zaspokajania popędów biologicznych. (List Biskupów Polskich na Dzień Świętej Rodziny, 11 XII 93)

Konstytutywną cechą języka kaznodziejskiego jest aksjologizacja - nastawienie na przekaz wartości. Wyraźnie zarysowaną cechą świata wartości wyłaniającego się $z$ analizowanych kazań jest jego nadmierne uproszczenie. Tendencja do symplifikacji ujawnia się zwłaszcza w sposobach prezentowania złożonych ludzkich wyborów, trudnych sytuacji i konfliktów wartości: 
21. W środkach masowego przekazu dominuje, niestety, ton nieprzyjazny poczętemu życiu. Toteż chciałbym wykorzystać szansę, jaką daje kazanie radiowe, aby powiedzieć słowo w obronie naszych poczętych dzieci, które z taką łatwością są $w$ nas zabijane. (79)

22. Dlaczego chrześcijańscy rodzice zabijają dzieci nie narodzone? A Polska dyskutuje, czy to dobrze, czy to źle? (305)

23. Wierzę, ale kłamać to wolno. Wierzę, ale zabijać to też powinno być wolno. Wierzę, ale modlić się w szkole to już nietolerancja.(353)

Nadmierne uproszczenie opisywanej rzeczywistości często, niestety, idzie w parze ze zjawiskiem bardzo niekorzystnym dla komunikacji: chodzi o takie pokierowanie świadomości słuchaczy, by treści, które mają służyć przekonaniu, pochodziły nie bezpośrednio od kaznodziei, lecz od tych, którzy reprezentują przekonania nie aprobowane. Podstawą językową takiego zabiegu psychologicznego jest wykorzystywanie mowy pozornie zależnej. Najzręczniejszym sposobem takiego ukształtowania wypowiedzi jest przytoczenie czyjegoś zdania, stanowiska, jednak nie w postaci dosłownej, lecz zinterpretowanej przez mówiącego. Uczestnicy polemiki o ustawie antyaborcyjnej, do których zdania odwołuje się kaznodzieja, z pewnością nie zgodziliby się, że podają w wątpliwość zło płynące z zabijania, z pewnością nie zgadzaliby się na prawo zabijania, $w$ ich ustach słowo aborcja nie jest przecież tak jak w ustach księdza synonimem morderstwa. Ukrywają się za tym: określona filozofia, złożone przekonania itd. To one w gruncie rzeczy stanowią etyczną postawę, która powinna być obiektem perswazyjnego oddziaływania kaznodziei.

Ważną ujemna cechą współczesnych tekstów homiletycznych jest ich narastający negatywizm: nastawienie bardziej na tępienie postaw i wartości nie akceptowanych niż prezentacja pożądanych. Obserwacja ich pod kątem najczęściej używanych w nich nazw wartości i antywartości wykazuje, że te drugie znaczenia dominują nad pierwszymi. Wniosek to o tyle ciekawy, że w czasach, gdy - zdawałoby się - całkiem naturalne było wskazywanie takich żywo odczuwalnych przez wiernych antywartości, jak kłamstwo, fałsz czy niewola, perswazja kaznodziejska opierała się bardziej na propagowaniu wartości pozytywnych, krzewieniu dobra niż tępieniu wartości negatywnych, zła. Stąd liczne użycia takich słów jak: prawda, miłość, dialog, sprawiedliwość, dobro, miłosierdzie, wolność.

W tekście skoncentrowałam się na niedostatkach współczesnego przepowiadania w Polsce. Nie znaczy to wszak, że nie dostrzegam rozległych pokładów dobra płynących $z$ tekstów kościelnych. W obliczu jednak narastającej niechęci wobec Kościoła kwestią pierwszoplanową dla językoznawcy, zwłaszcza jeśli czuje się z nim związany, jest zwracać uwagę na takie zjawiska, które mogą stanowić dla niego realne zagrożenie. Zagrożeniem przepowiadania kościelnego lat dziewięćdziesiątych jest, w moim odczuciu, uleganie modelowi komunikacji, który przedkłada „my” nad „ja”, kładzie nacisk na solidarność budowaną automatycznie, chętnie korzysta ze sztywnych schematów, nie wymaga od adresata refleksji, nie uwzględnia różnorodności doświadczeń mówiącego i słuchacza, podsuwa adresatom gotowe interpretacje zdarzeń. 